\title{
Kegagalan Pasar di Balik Ekspor Benih Lobster di Indonesia
}

\author{
Sherlly Rossa ${ }^{1}$, Silvestra Gratiana Tyas Vita Wimasari², Sulis Rah- \\ mawati ${ }^{3}$, dan Teddy Aprilianto Thomas ${ }^{4}$
}

Diserahkan: 29 Januari 2021 | Diterima: 25 Juni 2021 | Diterbitkan: 22 Juli 2021

\begin{abstract}
Abstrak
Indonesia merupakan negara eksportir utama benih lobster pada negaranegara produsen lobster di dunia. Penetapan Permen KP Nomor 12 Tahun 2020 menjadi titik balik dengan asumsi kesejahteraan nelayan, peningkatan ekonomi, dan devisa menjadi dalih utama dalam proses penetapannya. Kausalitas yang dihasilkan dari penetapan Permen KP Nomor 12 memicu terjadinya suatu aksi tragedi sumber daya kepemilikan bersama yang dimanfaatkan sebagai lahan untuk mencari keuntungan sebesarbesarnya yang mencerminkan suatu paham merkantilisme. Selain itu, eksternalitas dan ketidakefisiensi pasar akan menjadi permasalahan baru yang berkepanjangan karena tidak terpenuhinya prinsip ekonomi yang berwawasan dan keberlanjutan lingkungan dalam proses pelaksanaannya. Adanya disparitas harga antara nelayan dan eksportir yang begitu terlihat

\begin{tabular}{|c|c|c|c|c|c|}
\hline 1 & Departemen $\quad$ Politik & Pemerintahan, & Universitas & Gadjah & Mada. \\
\hline & \multicolumn{5}{|c|}{ Email: sherllyrossa@mail.ugm.ac.id. } \\
\hline 2 & \multicolumn{5}{|c|}{ Email: silvestragratiana@mail.ugm.ac.id. } \\
\hline 3 & $\begin{array}{l}\text { Departemen Politik } \\
\text { Email: sulisrahmawati@ma }\end{array}$ & $\begin{array}{l}\text { Pemerintahan, } \\
\text { n.ac.id. }\end{array}$ & Universitas & Gadjah & Mada. \\
\hline 4 & Departemen & Pemerintahan, & Universitas & Gadjah & Mada. \\
\hline
\end{tabular}
\end{abstract}


menimbulkan pertanyaan bagi pemerintah mengenai dalih diberlakukannya Permen KP Nomor 12 Tahun 2020. Oleh karena itu, tulisan ini mencoba menganalisis dasar kebijakan Permen KP Nomor 12 Tahun 2020 dalam hubungan dengan keberlanjutan kesetersediaan sumber daya kelautan hingga implementasinya dalam mendorong net ekspor pertumbuhan ekonomi Indonesia. Metode penelitian inimenggunakan pendekatan kuantitif dan kualitatif berupa tabel, grafik, dan studi pustaka dari sumber relevan yang berhasil menjelaskan fenomena ini. Hasil penelitian menunjukkan bahwa keberlanjutan sumber daya laut akan menjadi problematik bagi negara apabila kebijakan yang dikeluarkan dengan dalih kesejahteraan nelayan berbanding terbalik dengan tujuan utamanya.

Kata kunci: Benih lobster; Permen KP Nomor 12 Tahun 202O; Disparitas harga; Eksternalitas; Tragedi bersama; Devisa

\section{PENDAHULUAN}

Pada tanggal 4 Mei 2020, Menteri Kelautan dan Perikanan Republik Indonesia periode 2019-2020, Edhy Prabowo, menetapkan Permen KP Nomor 12 Tahun 2020 yang memberikan izin ekspor benih lobster dari wilayah Republik Indonesia. Kegiatan tersebut dilarang oleh Menteri sebelumnya, Susi Pujiastuti, melalui Peraturan Menteri Kelautan dan Perikanan Republik Indonesia Nomor 56 Tahun 2016 tentang penangkapan dan/atau pengeluaran lobster, kepiting, dan rajungan dari wilayah Indonesia. Peraturan tersebut memberi syarat lobster boleh diperdagangkan dengan berat di atas 200 gram. Pertimbangannya didasarkan pada 
keberlanjutan hidup dari lobster-lobster berikutnya yang akan bertelur sehingga dapat meninggalkan benih baru bagi Indonesia jika diekspor.

Kebijakan tersebut kemudian direvisi menjadi Permen KP Nomor 12 Tahun 2020 yang diperuntukkan guna menjaga keberlanjutan ketersediaan sumber daya perikanan, peningkatan kesejahteraan masyarakat, kesetaraan teknologi budaya, pengembangan investasi, peningkatan devisa negara, dan pengembangan pembudidayaan lobster. Menurut Edhy Prabowo, regulasi tersebut dapat membantu meningkatkan perekonomiannelayanyang kehilanganmatapencaharian sejak dibekukan oleh menteri sebelumnya. Penangkapan benih lobster sebagai mata pencaharian sudah marak dilakukan oleh masyarakat.

Kebijakan yang dikeluarkan pada era pemerintahan Edhy tersebut memang menuai banyak kontroversi. Pemerintah juga beralasan kebijakan ini ditujukan untuk meningkatkan kesejahteraan melalui proses perizinan yang mudah (Idris, 2020). Pemberian izin yang dilakukan Edhy memiliki syarat utama untuk menghidupi nelayan yang selama ini hidup dari komoditas tersebut (Ambari dan Jay, 2020). Edhy juga menyampaikan kepada media bahwa kebijakan ini tak 
hanya untuk korporasi, tetapi juga kehidupan 13.000 nelayan benih lobster (Idris, 2020).

Alih-alih menyejahterakan nelayan, gaya kepemimpinan Edhy yang populistik malah membuatnya tersandung masalah korupsi. Biasanya, pemimpin populis mengklaim bahwa mereka mewakili keinginan rakyat kecil dengan menentang kebijakan yang tidak pro rakyat (Moffitt, 2016). Pada kasus ini, terlihat Edhy menonjolkan dirinya ketika merevisi Permen KP Nomor 56 Tahun 2015 yang menyebabkan penurunan volume ekspor benih lobster. Lahirlah Permen KP Nomor 12 Tahun 2020 yang menurut Edhy lebih "memudahkan" pemberian izin ekspor benih lobster.

Efek "kemudahan" yang diberikan mulai terasa ketika ekspor benih lobster yang baru dibuka Mei 2020 yang menimbulkan kejanggalan sejak awal ketika beberapa pengusaha dapat mendahului melakukan kegiatan ekspor. Padahal, Permen KP Nomor 12 Tahun 2020 mengharuskan mereka yang hendak mengekspor untuk melakukan budi daya terlebih dahulu. Hal ini mengacaukan checks and balances dari sistem ekspor benih lobster.

Namun, tak dapat dimungkiri bahwa dorongan untuk mendatangkan devisa melalui ekspor benih 
lobster dilakukan tidak sesuai dengan skema, demi mendobrak keuntungan sebanyak-banyaknya. Dengan demikian, beberapa pengusaha "terpaksa" mengekspor benih lobster tanpa melakukan budi daya, seperti yang tercantum pada permen KP. Fenomena ini membuktikan bahwa dilema sosial itu nyata adanya.

Selanjutnya, pada 26 November 2020, Komisi Pemberantasan Korupsi (KPK) telah menetapkan Edhy Prabowo selaku Menteri Kementerian Kelautan dan Perikanan (KKP) sebagai tersangka dugaan suap izin ekspor benih lobster (Rahma, 2020). Mengutip dari siaran pers KPK (2020), menetapkan tujuh orang tersangka dari 17 orang yang diamankan. Edhy Prabowo yang diamankan bersama dengan orangorang terdekatnya, membuktikan bahwa seorang agen memiliki daya intervensi di sekeliilingnya untuk memengaruhi tindakan agen lain.

Korupsi sebagai kejahatan struktural memiliki pola dan stuktur yang sama karena adanya potensi-potensi yang terus dirasionalisasi oleh agen-agennya. Struktur penandaan melihat korupsi terbentuk karena agen yang ada secara aktif menciptakan makna pada tataran yang direproduksi dalam kehidupan sehari-hari. Tindakan kejahatan (Korupsi) tidak terlepas dari jaringan tindakan produksi dan reproduksi struktur oleh agen. 
Giddens (1990: 48) berpendapat bahwa kehidupan manusia modern cenderung mengambil jalan pintas dan tindakan praktis.

Sama halnya dengan Edhy, Menteri Kelautan dan Perikanan ini menginginkan adanya tindakan praktis. Tindakan rasional yang dengan mengatasnamakan kesejahteraan rakyat ini bertujuan untuk mempermudah kegiatan perizinan. Sayangnya, dengan gaya kepemimpinan populis justru membuat Edhy dan agen lainnya melakukan tindakan berulang yang diam-diam tidak dapat meluruskan pernyataan diskursif secara langsung.

\section{EKSPLOITASI LOBSTER: DISPARITAS HARGA DAN EKSTERNALITAS}

Salah satu alasan Kementerian Kelautan dan Perikanan mengeluarkan Peraturan Menteri Nomor 12 Tahun 2020, yaitu terkait banyaknya keluhan nelayan penangkap lobster yang kehilangan mata pencahariannya sejak Peraturan Menteri Nomor 56 Tahun 2016-yang melarang pengambilan benih lobster untuk dibudidayakan-diberlakukan. Tetapi, kebijakan yang diambil oleh Edhy Prabowo ini belum dapat berbuah manis bagi para nelayan dalam negeri. Maka 
dari itu, nelayan lokal lebih senang mengekspor hasil tangkapan mereka.

Direktur Jenderal Perikanan Tangkap KKP, Zulficar Mochtar, pun mengatakan sebelum melakukan ekspor, eksportir wajib memenuhi persyaratan, seperti berhasil memanen budi daya lobster dengan melepasliarkan dua persen dari hasil panen (Ambari dan Jay, 2020). Adapun syarat kuota ekspor benih lobster untuk perusahaan belum ditetapkan. Tetapi, pemerintah telah menerapkan kuota ekspor sebanyak 139.475.00o ekor per tahun dengan alokasi 70 persen untuk budi daya dan 30 persen untuk ekspor.

Penerapan alokasi tersebut ditujukan agar keseimbangan ekosistem tetap terjaga akibat eksploitasi. Argumen ini diperkuat dengan kajian akademis yang meneliti persentase kelangsungan hidup (survival rate) benih lobster di laut lepas tanpa budi daya hanya sebesar $0,02 \%$ atau hanya ada satu dari 20.000 lobster yang akan hidup hingga dewasa (Ambari dan Jay, 2020). Sebaliknya, budi daya dapat meningkatkan survival rate antara 30\% -8 o\% tergantung metode yang digunakan.

Saat ini, para nelayan merasa sering merugi karena biaya operasional untuk mencari lobster tidak sebanding dengan harga jualnya. Kepala Departemen Advokasi 
Eksekutif Nasional, Zenzi Suhadi, mengungkapkan bahwa harga jual yang diterima nelayan saat ini tidak sampai sepuluh persen dari harga ekspor (Rosana, 2020). Harga jual benih lobster di tingkat nelayan, hanya berkisar Rp4.000-Rp9.000, padahal rata-rata tarif harga jual ekspor yang dipatok eksportir setelah benih lobster diperdagangkan ke luar negeri mencapai US\$13 untuk jenis mutiara, dengan kurs yang berlaku saat ini, harga jual tersebut setara dengan Rp180.00o per ekor. Peraturan yang awalnya dibuat demi meningkatkan kesejahteraan nelayan justru berpeluang membawa dampak yang cukup buruk pada nelayan karena waktu dan tenaga yang dikeluarkan tidak sebanding dengan nilai jual yang mereka terima.

Adanya kesenjangan harga jual ekspor dapat ditinjau dengan teori disparitas harga. Disparitas harga terjadi karena adanya perbedaan harga yang sangat signifikan terhadap suatu harga, dalam hal ini kesenjangan harga antara nelayan dan harga yang dipatok oleh eksportir. Dikutip dari portal berita tempo.co, perbedaan harga juga terjadi di antara satu wilayah dengan wilayah lain sesama penghasil benih ekspor. Disparitas harga benih di tingkat nelayan dengan pasar ekspor juga menjadi salah satu dampak yang merugikan bagi penangkap benih lobster. Harga benih lobster tangkapan nelayan 
hanya berkisar Rp30oo hingga Rp50oo per ekor, tetapi di Vietnam harga benih lobster mencapai Rp139 ribu per ekor (Hidayatulla, 2020).

Menurut Ketua Harian DPP Kesatuan Nelayan Tradisional Indonesia (KNTI), Dani Setiawan, perbedaan harga ini terjadi karena beberapa faktor, yaitu terkait kesiapan infrastruktur dan transportasi. Wilayah yang memiliki fasilitas yang memadai cenderung memiliki harga yang lebih mahal dibandingkan dengan wilayah dengan fasilitas yang kurang memadai.

Ketimpangan harga yang terus berlanjut dapat menimbulkan dampak jangka pendek dan jangka panjang. Dampak jangka pendek, nelayan dengan segala risikonya tidak dapat memaksimalkan diri untuk mengembangkan potensi guna meningkatkan kesejahteraannya. Dampak jangka panjang, apabila patokan harga jual masih rendah, hal ini dapat memicu terjadinya ekspor illegal, bahkan melebihi kuota dapat menyebabkan berkurangnya ketersediaan lobster di alam.

Selain berdampak pada harga, ekspor benih lobster yang dilakukan secara besar-besaran berdampak pula pada kondisi lingkungan. Lobster, biasanya hidup dan berkembang di dalam terumbu karang. Indonesia 
dikenal memiliki wilayah perairan yang didominasi oleh terumbu karang yang menjadi habitat terbaik bagi lobster. Namun, apabila benih lobster yang diambil untuk keperluan ekspor ditangkap menggunakan alat tangkap yang tidak ramah lingkungan, hal ini dapat menyebabkan kerusakan pada terumbu karang. Selain itu, kerusakan terumbu karang akan berdampak pada keberlanjutan biota laut lain yang tinggal di dalam terumbu karang tersebut.

Permasalahan lain terkait kondisi lingkungan yang tak kalah penting adalah keberadaan lobster merupakan salah satu sumber daya yang terbatas jumlahnya jika dibandingkan dengan tingkat konsumsi masyarakat yang terus bertambah. Lobster termasuk dalam kategori plasma nutfah yang secara genetik keberlanjutannya belum bisa direkayasa oleh manusia. Aktivitas penangkapan dan ekspor benih lobster pun masif berlangsung tanpa pengawasan sehingga dalam jangka panjang dapat menyebabkan kepunahan secara signifikan.

Dalam teori ekonomi, terjadinya kerusakan lingkungan yang disebabkan manusia dapat dijelaskan melalui teori eksternalitas. Fisher (1996) mengatakan bahwa eksternalitas terjadi bila suatu aktivitas pelaku ekonomi (baik produksi maupun konsumsi) 
mempengaruhi kesejahteraan pelaku ekonomi lain dan peristiwa yang ada terjadi di luar mekanisme pasar (Mukhlis, 2009). Eksternalitas terjadi karena adanya perbedaan antara marginal social dan private cost suatu barang. Secara umum, eksternalitas memiliki dua macam bentuk, yaitu positif dan negatif. Eksternalitas positif adalah keuntungan terhadap pihak ketiga selain penjual dan pembeli barang atau jasa yang tidak direfleksikan dalam harga. Ketika terjadi eksternalitas positif, harga tidak sama dengan keuntungan sosial tambahan (marginal social benefit) dari barang dan jasa yang ada (Yuniarti, 2019).

Eksternalitas negatif (biaya eksternal) adalah biaya terhadap pihak ketiga selain pembeli dan penjual pada suatu macam barang yang tidak direfleksikan dalam harga pasar. Ketika terjadi eksternalitas negatif, harga barang/jasa tidak menggambarkan biaya sosial tambahan (marginal social cost) secara sempurna pada sumber daya yang dialokasikan dalam produksi (Yuniarti, 2019). Secara sederhana, eksternalitas positif adalah aktivitas ekonomi yang memberikan manfaat kepada pihak ketiga, tetapi manfaat tersebut tidak dialokasikan di pasar, sedangkan eskternalitas negatif adalah aktivitas ekonomi yang memberikan efek negatif 
kepada pihak ke-3, tetapi tidak berdampak apa pun pada dirinya.

Dampak eksternalitas negatif dapat dijelaskan menggunakan kurva berikut ini.

Figur 1. Kurva Eksternalitas Negatif

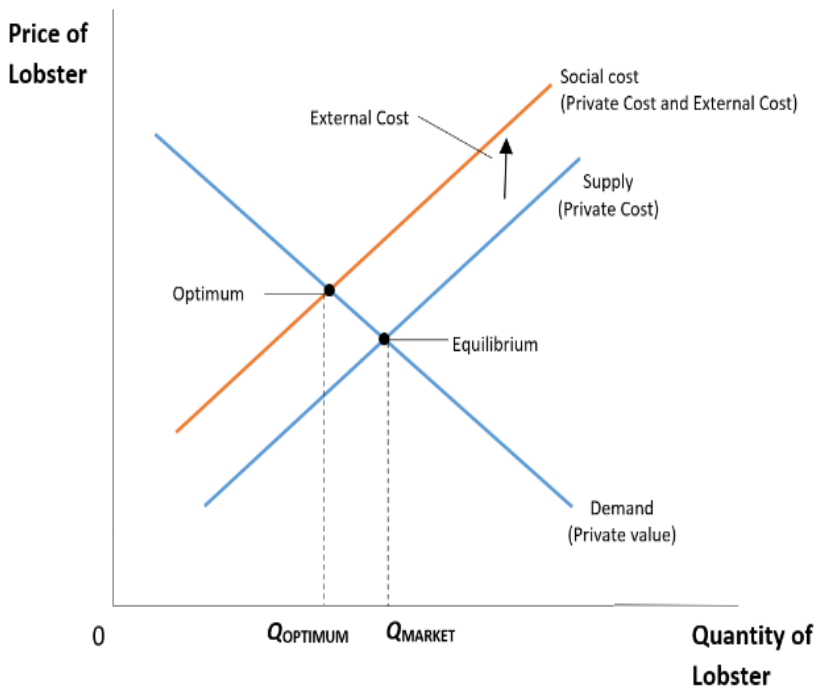

Sumber: Principles of Economics, 2012, diolah

Pada kasus ini, penangkapan benih lobster menggunakan alat-alat yang tidak ramah lingkungan dapat mengakibatkan kerusakan pada terumbu karang sebagai habitat lobster. Apabila terumbu karang rusak, hal ini berisiko pula pada keberlanjutan biota laut lain yang hidup di dalamnya. Dalam hal ini, eksternalitas negatif memengaruhi efisiensi hasil pasar. 
Eksternalitas yang menjadi penyebab biaya bagi masyarakat untuk memproduksi lobster lebih besar daripada biaya produksi bagi para produsen lobster. Setiap lobster yang diproduksi akan menambah biaya sosialnya bagi kerusakan lingkungan sebagai dampak buruk daripenangkapan dengan alattangkapyang kurang ramah lingkungan. Kurva biaya sosial terletak di atas kurva penawaran karena kurva ini memperhitungkan biaya-biaya eksternal yang dibebankan oleh masyarakat terhadap produsen yang menyebabkan terciptanya dampak buruk pada lingkungan. Khususnya, dalam kasus ini adalah penangkap lobster.

Alasan dari ketidakefisiensi pasar ini bermula dari keseimbangan pasar yang hanya mencerminkan biayabiaya swasta dari produksi (Mankiw, 2012). Di dalam keseimbangan pasar, konsumen marginal menghargai lobster di bawah biaya sosial untuk memproduksinya. Pada Q pasar, kurva permintaan berada di bawah kurva biaya sosial. Dengan demikian, mengurangi produksi lobster beserta konsumsinya hingga di bawah keseimbangan pasar akan meningkatkan kesejahteraan ekonomi total.

Salah satu cara yang dapat dilakukan untuk mencapai hasil yang optimal adalah dengan memberlakukan pajak kepada para produsen (penangkap) lobster untuk 
setiap ton yang terjual. Pajak ini dapat menggeser kurva penawaran lobster ke atas sebesar nilai pajak itu. Apabila pajak ini benar-benar mencerminkan biaya eksternal dari kerusakan terumbu karang, kurva penawaran yang baru akan menempel dengan kurva biaya sosial. Dalam keseimbangan pasar yang baru, produsen (penangkap) lobster akan memproduksi jumlah yang optimal secara sosial.

Adapun Susan Herawati, Sekretaris Jenderal Koalisi Rakyat untuk Keadilan Perikanan (KIARA) yang mengutip data dari Bea dan Cukai Kementerian Keuangan RI menyampaikan bahwa perusahaan eksportir yang mendapatkan izin hanya dibebani Penerimaan Negara Bukan Pajak (PNBP) sebesar Rp15.00o per 60.000 ekor lobster (Ambari dan Jay, 2020). Berarti, bisa dibayangkan jika perusahaan ekportir menjual benih seharga Rp139.000 dan membayar PNBP sebesar Rp15.000-menjual 60.000 ekor lobster-, keuntungan yang akan mereka peroleh sekitar Rp8.340.000.00o. Jelas pada kasus ini, nelayan tradisional "dibodohi" oleh para stakeholder.

Akibat dari adanya eksternalitas ini, ekuilibrium pasar tidak mampu lagi memaksimalkan kesejahteraan total bagi masyarakat secara keseluruhan. Aktivitas budi daya lobster di Indonesia saat ini belum optimal 
dimana hanya 3,09\% produksi lobster di Indonesia yang bersumber pada budi daya, sedangkan sisanya sebesar 96,91\% bersumber dari perikanan tangkap (Yunianto, 2020). Dalam hal ini, pasokan benih lobster masih tergantung pada penangkapan di alam dan ketersediaan benih lobster tersebut sangat tergantung pada kondisi lingkungan. Tetapi, apabila melihat dari kasus tersebut, eksternalitas ini timbul akibat dari aktivitas manusia yang tidak mengikuti prinsip-prinsip ekonomi yang berwawasan lingkungan (Dina dan Hasanah, 2020).

Dalam kasus ini, eksternalitas negatif menyebabkan inefisiensi atau kegagalan pasar (market failure). Kegagalan pasar terjadi ketika mekanisme pasar tidak mampu mengalokasikan sumber-sumber ekonomi yang ada dalam masyarakat secara efisien. Eksternalitas dan ketidakefisienan pasar timbul karena tidak terpenuhinya salah satu atau beberapa prinsip alokasi sumber daya yang efisien. Ketika hal ini terjadi, dalam jangka panjang dapat menimbulkan dampak yang merugikan bagi perekonomian.

Menurut Imam Mukhlis (2009), eksternalitas akan menimbulkan masalah apabila produsen maupun konsumen menyebabkan pengaruh eksternal (external effects), yaitu apabila aktivitas produsen maupun konsumen menyebabkan biaya atau manfaat pada pihak 
ketiga yang akan muncul karena biaya atau pun manfaat eksternal tersebut tidak dimasukkan dalam perhitungan oleh konsumen maupun produsen. Akibatnya, aktivitas yang terjadi adalah baik konsumen maupun produsen cenderung meremehkan biaya eksternal (external cost). Oleh karena itu, dimungkinkan produsen maupun konsumen menghasilkan output dengan kuantitas yang lebih besar dari kondisi output efisien. Padahal, apabila output tersebut dihasilkan lebih sedikit (tingkat efisien), maka kerugian yang diderita orang lain dapat berkurang (Mukhlis, 2009).

Dalam hal ini, pemerintah perlu mengadakan government intervention dalam bentuk penetapan pajak atau subsidi yang dimungkinkan untuk mengatasi masalah internalitas ini. Apabila terjadi biaya eksternal (external cost), pemerintah dapat mengenakan pajak sebesar biaya eksternal tambahan (marginal external cost) terhadap pihak yang menimbulkan eksternalitas negatif (Mukhlis, 2009). Pajak ini akan mendorong baik bagi konsumen maupun produsen atau pihak yang menimbulkan eksternalitas untuk memasukkan biaya-biaya eksternal yang ada ke dalam suatu keputusan ekonomi, yang dapat diartikan bahwa pelaku eksternalitas akan membayar sejumlah biaya sebesar 
biaya eksternal tambahan (marginal external cost) per unit output yang terjual (Mukhlis, 2009).

\section{TRAGEDI BERSAMA: PENYELUNDUPAN}

Saat ini, kondisi budi daya lobster masih belum optimal dan ketersediaan benih lobster di alam tidak dapat diprediksi. Kondisi ini didukung dengan belum tersedianya data akuratterkaitpotensilobster.Akibatnya, sumber daya lobster yang bersifat milik bersama dan bisa diakses oleh siapa saja akan mengakibatkan munculnya tragedi sumber daya kepemilikan bersama atau tragedy of the commons. Teori the tragedy of the commons ini diperkenalkan oleh Garret Hardin (1968). Hardin menjelaskan bahwa sumber daya yang sifatnya milik bersama (common property) akan rentan untuk dieksploitasi dan mengakibatkan kerusakan lingkungan yang akan merugikan banyak pihak. Untuk mengatasi masalah ini, Hardin mengatakan bahwa sumber daya milik bersama akan dapat dikelola dengan baik melalui pemerintah atau swasta. Namun pada kenyataannya, sumber daya milik bersama tidak selalu dapat dikelola secara efektif oleh pemerintah maupun swasta (Iskandar, 2006). Dalam hal ini, kasus korupsi yang dilakukan oleh Edhy Prabowo adalah salah satu hal yang bisa dikatakan sebagai the tragedy of the commons. Pencabutan aturan 
larangan ekspor dan penangkapan benih lobster-yang sudah ditetapkan oleh Menteri Kelautan dan Perikanan 2014-2019, Susi Pudjiastusti melalui Peraturan Menteri KP Nomor 12/Peremen-KP/2020-dimanfaatkan oleh Edhy Prabowo demi keuntungan pribadi melalui kekuasaan yang ia miliki sebagai Menteri Kelautan dan Perikanan serta membahayakan keberlanjutan lingkungan.

Kasus tragedi bersama dalam ekspor lobster ini juga dapat kita lihat melalui sudut pandang rational choice. Pandangan ini mengatakan bahwa individu mempertimbangkan cost and benefit dalam mengambil keputusan. Pandangan ini bertolok dari asumsi bahwa manusia itu rasional dan self-interest (Hindmor \& Taylor, 2018). Dalam hal ini, Edhy Prabowo terlihat sedari awal bahwa ia menentukan kebijakan yang berorientasi keuntungan. Pertama, Edhy memilih untuk mengekspor benih lobster yang akan dengan cepat menghasilkan keuntungan daripada membudidayakannya karena Indonesia juga belum mampu untuk hal tersebut. Kedua, Edhy menjadikan para nelayan yang menganggur karena tidak dapat menangkap benih lobster menjadi alasan untuk membuka kembali keran ekspor benih lobster. Dalam hal ini, dapat kita lihat bahwa Edhy mengambil 
solusi shortcut yang menggunakan cost lebih sedikit dan menghasilkan benefit besar serta dapat dirasakan dengan cepat hasilnya.

Sejak awal, munculnya wacana pembukaan keran ekspor benih lobster kembali oleh Edhy Prabowo ini berakibat pada meningkatnya harga benih lobster. Saat itu, harga benih lobster naik sepuluh kali lipat. Padahal, biasanya benih lobster dibeli dengan harga dua ribu rupiah per ekor, tetapi saat itu, harganya meningkat hingga dua puluh ribu rupiah per ekor (Fitra dan Lidwina, 2020).

Jika dilihat dari sisi harga penjualan, tentu saja penjualan lobster yang sudah besar akan lebih mahal dibandingkan dengan harga penjualan bibit lobster. Begitu pun dengan keuntungan yang akan didapat para petani lobster ketika mereka menjual lobster yang sudah besar bukan bibit lobster. Hal ini diperkuat dengan pernyataan Direktur Program Institute for Development of Economics and Finance (INDEF), Esther Sri Astuti, bahwa ekspor benih lobster tidak akan memberikan nilai tambah. Benih lobster jika dijual hanya dihargai sebesar Rp130.00o sampai Rp140.ooo per ekor, sementara jika lobster dengan berat 12-14 kilogram diekspor, harganya bisa mencapai Rp4 juta sampai Rp5 juta per ekor (Fadli, 2019). 
Pada masa Susi Pudjiastuti, ketika benih lobster dilarang untuk diekspor dan ditangkap, hal ini mengakibatkan 5.623 orang penangkap benih lobster di seluruh provinsi Nusa Tenggara Barat kehilangan potensi pendapatan yang diprediksi mencapai Rp35,14 miliar sampai Rp54,07 miliar per bulan (Figur 2). Jika waktu efektif penangkapan benih adalah sekitar delapan bulan dalam setahun, masyarakat diprediksi kehilangan pendapatan sebesar Rp281 miliar sampai Rp433 miliar per tahun. Dampak lainnya adalah meningkatnya penyelundupan benih lobster dan terhentinya aktivitas budi daya pembesaran lobster akibat dari mahalnya harga benih. Selain itu, pelarangan penangkapan lobster juga mengakibatkan pada meningkatnya jumlah pengangguran karena pada umumnya para penangkap benih lobster tidak memiliki mata pencahariaan lain. Hal ini mengakibatkan meningkatnya angka pencurian dan perampokan, baik terhadap masyarakat lokal sendiri maupun wisatawan dari luar pulau (Erlania et.al., 2017). 


\section{Figur 2. Jumlah Masyarakat Penangkap Benih Lobster pada Beberapa Lokasi di Lombok, Nusa Tenggara Barat}

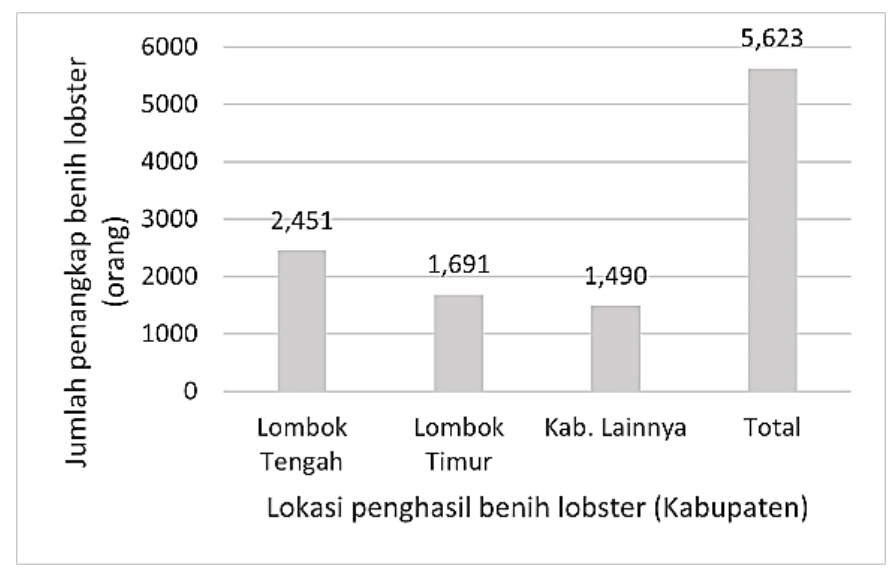

Sumber: SKP-NTB, 2015

Aturan diperbolehkannya lagi ekspor benih lobster berdampak pada kelestarian lobster. Dalam kurun waktu jangka panjang, hal ini bisa berdampak pula pada perekenomian penangkap lobster. Salah satu alasan dibukanya kembali ekspor benih lobster adalah Indonesia belum mampu melakukan budi daya benih lobster tersebut hingga menjadi lobster. Jika benih lobster diekspolitasi, hal ini dapat mempercepat habisnya benih lobster di alam. Kebijakan ekspor benih lobster ini dianggap hanya menguntungkan dalam jangka pendek. Akan lebih banyak kerugian yang dihasilkan daripada keuntungan yang ditawarkan jika 
ekspor benih lobster dilakukan. Selain itu, kebijakan ini juga hanya menguntungkan industri budi daya lobster di negara tujuan ekspor benih lobster, salah satunya Vietnam. Diperkirakan hasil budi daya lobster di Vietnam akan meningkat karena kembali mendapat pasokan benih dari Indonesia. Hal ini dikatakan oleh Tenaga Ahli Individual Bidang Ekonomi Kelautan dan Perikanan, Suhana (Hidayatulla, 2020).

Selain berdampak pada penangkap benih lobster, permasalahan ekspor benih lobster juga terjadi pada distribusi. Menteri Koordinator Kemaritiman dan Investasi sekaligus Menteri Kelautan dan Perikanan, Luhut Panjaitan, mengakui adanya praktik monopoli pengangkutan ekspor benih lobster yang hanya dilakukan oleh satu perusahaan. Sebelumnya, hal ini juga telah disampaikan oleh Komisi Pengawas Persaingan Usaha (KKPU). Dugaan monopoli ini muncul karena pengiriman benih lobster hanya dilakukan oleh satu bandara, yaitu Bandara Soekarno-Hatta. Padahal, ada lima pilihan bandar udara lain yang dapat menjadi akses pengiriman benih lobster ke luar negeri. Hal ini dikhawatirkan akan menimbulkan inefesiensi bagi biaya pengiriman dan risiko bagi pelaku usaha (Wicaksono, 2020). 
Dampak lain dari adanya larangan ekpor benih lobster, yaitu meningkatnya kasus penyelundupan bibit lobster. Dengan dibukanya keran ekspor benih lobster, praktik penyeludupan benih lobster menjadi semakin marak tanpa memperhatikan regulasi yang ada, dikarenakan hanya berorentasi pada keuntungan tertentu (Rosana dan Wahyudi, 2020). Tingginya harga dan permintaan pasar terhadap benih lobster akan mendorong nelayan untuk melakukan eksploitasi tanpa memikirkan dampak bagi keberlanjutan ekosistem dan lingkungan. Selama periode 2015 hingga Juni 2019 terdapat 254 kasus penyelundupan benih lobster yang berhasil digagalkan. Total benih lobster yang berhasil digagalkan penyelundupannya mencapai 8,6 juta ekor dengan total nilai Rp1,2 triliun (BKIPM, 2019).

\section{Tabel 1. Kerugian Penyelundupan Benih Lobster di Indonesia tahun 2014-2017}

\begin{tabular}{|c|c|}
\hline Tahun & Besar Kegiatan \\
\hline 2014 & Rp27,3 Miliar \\
\hline 2015 & Rp130 Miliar \\
\hline 2016 & Rp166 Miliar \\
\hline 2017 & Rp336 Miliar \\
\hline
\end{tabular}

Sumber: Journal of International Relations, 2019

Faktor internal penyelundupan ini dapat disebabkan karena minat konsumsi masyarakat Indonesia terhadap 
lobster masih rendah (Adhitama, 2019). Selain itu, Kementerian PPN/ Bappenas (2014) juga menyampaikan bahwa harga produk perikanan yang sampai ke tangan konsumen cenderung mahal karena pendistribusian yang lambat. Di sisi lain, harga benih cenderung murah. Tawaran menggiurkan ini dimanfaatkan oleh importir dengan membeli benih yang dapat dibudidayakan sendiri. Ketika ukuran lobster sudah mencapai ukuran konsumsi, lobster dapat dijual dengan harga yang lebih mahal. Mengutip dari tulisan Adhitama (2019), tercatat pada 2014, harga benih lobster Rp20.0oo per ekor untuk jenis mutiara dan Rp17.00o per ekor untuk jenis pasir. Adhitama (2019) menambahkan data 2018 menunjukkan peningkatan yang cukup signifikan karena harga benih lobster jenis mutiara menjadi Rp79.00o-Rp90.0oo per ekor dan Rp18.0oo-Rp26.0oo untuk jenis pasir. Harga murah yang ditawarkan Indonesia tersebut menjadi keuntungan tersendiri bagi nelayan Vietnam. 
Tabel 2. Harga Beli Lobster Berdasarkan Ukuran dan Jenis Setiap Tahapan Pemasaran

\begin{tabular}{|c|c|c|c|c|c|c|}
\hline $\begin{array}{l}\text { Jenis/ } \\
\text { Type }\end{array}$ & $\begin{array}{l}\text { Ukuran/ } \\
\text { Size }\end{array}$ & $\begin{array}{l}\text { Nelayan/ } \\
\text { Fisherman }\end{array}$ & $\begin{array}{l}\text { Pedagang } \\
\text { Pengumpul } \\
\text { Dusun/Desa/ } \\
\text { Village Traders }\end{array}$ & $\begin{array}{l}\text { Pedagang/ } \\
\text { Pengumpul } \\
\text { Besar/ } \\
\text { Big Traders }\end{array}$ & $\begin{array}{l}\text { Eksportir/ } \\
\text { Exporter }\end{array}$ & $\begin{array}{l}\text { Pembudidaya } \\
\text { Vietnam/ } \\
\text { Farmer in } \\
\text { Vietnam }\end{array}$ \\
\hline \multirow[t]{3}{*}{ Pasir } & $2-3$ & 14.000 & 16.000 & 20.000 & $\$ 2,5$ & \multirow{7}{*}{ $\pm 150,000$} \\
\hline & $4-5$ & 14.000 & 16.000 & 21.000 & $\mathrm{~N} / \mathrm{A}$ & \\
\hline & $6-8$ & 14.000 & 19.000 & 22.000 & $\mathrm{~N} / \mathrm{A}$ & \\
\hline & & & & & & \\
\hline \multirow[t]{3}{*}{ Mutiara } & $2-3$ & 14.000 & 19.000 & 24.000 & $\$ 4$ & \\
\hline & $4-5$ & 14.000 & 17.000 & 25.000 & $\mathrm{~N} / \mathrm{A}$ & \\
\hline & $6-8$ & 14.000 & 20.000 & 26.000 & $\mathrm{~N} / \mathrm{A}$ & \\
\hline
\end{tabular}

Sumber: Jurnal Kebijakan Sosial Ekonomi Kelautan dan Perikanan, 2015

Sekertaris Jendral KIARA, Susan Herawati, mendesak Menteri KKP untuk segera menghentikan ekspor benih lobster. Susan menganggap bahwa Menteri KKP seharusnya dapat memberantas praktik penyeludupan benih-benih lobster dan bukan malah membuka keran ekspor. Berdasarkan catatan Pusat Data dan Informasi KIARA pada 2019, KKP telah berhasil menyelamatkan negara dari penyelundupan lobster sebanyak 6.669.134 ekor, terhitung sejak 20142019 pada masa Susi Pujiastuti. Perkiraan uang yang telah diselamatkan mencapai Rp635,59 miliar (Victoria, 2020). 


\section{DEVISA: EKSPOR LOBSTER SEBAGAI SPESIALISASI INDONESIA}

Keinginan pemerintah untuk kembali membuka keran ekspordiperkuatdengan dalih untuk meningkatkan devisa negara karena harga jual lobster yang tinggi di pasar (Hikmah, 2020). Devisa diperoleh setelah melakukan hubungan atau transaksi dagang dengan negara lain. Sistem ekonomi terbuka yang berlaku di Indonesia mendukung kegiatan perdagangan internasional. Menurut Tambunan (2001), perdagangan internasional dapat diartikan sebagai perdagangan antarlintas negara yang di dalamnya terdapat ekspor dan impornya. Kedua pihak yang menjalin kerja sama harus mempunyai kebebasan untuk menentukan untung rugi dari pertukaran tersebut, dari sudut kepentingan masingmasing, kemudian menentukan apakah ia mau melakukan pertukaran atau tidak (Boediono, 1982). Berdasarkan teori David Ricardo "Comparative Advantage", setiap negara di dunia memproduksi barang dan jasa dengan spesialisasi negara tersebut (Bernhofen dan Brown, 2018). Kegiatan ini memungkinkan setiap negara di dunia berpotensi untuk melakukan pertukaran sumber daya yang dimiliki masing-masing negara dengan tujuan untuk mengurangi kelebihan atau pun kekurangan sumber daya di masing-masing negara di dunia. 
Menteri Kelautan dan Perikanan, Edhy Prabowo, mengklaim bahwa ekspor benih lobster mampu meningkatkan devisa negara. Adapun data yang ditampilkan oleh BBC News Indonesia (2020) menunjukkan bahwa nilai ekspor lobster meroket tajam semenjak keran ekspor lobster dibuka pada Mei 2020. Data Badan Pusat Statistik (BPS) mencatat benih lobster yang diekspor sejak Juni 2020 sebesar 32 Kilogram dengan nilai US\$ 112.990. Pada bulan Juli, volume ekspor benih lobster mengalami peningkatan menjadi 1.389 dengan nilai US\$ 3,67 juta dan sebulan setelahnya kembali meningkat tiga kali lipat menjadi 4.216 kilogram dengan nilai US\$ 6,43 juta. Selanjutnya di bulan Agustus, nilainya mencapai Rp9oo miliar. Selama bulan September 2020, ekspor benih lobster mencapai 15,16 juta dolar AS untuk $6.024 \mathrm{~kg}$ benih lobster (Thomas, 2020). Ekspor pada bulan September ini, sebagian besar ditujukan ke Vietnam, yaitu sebanyak 15,10 dolar AS. Akumulasi pada bulan Juni-Oktober, ekspor benih lobster RI sudah menyentuh US\$ 33.99 juta dengan jumlah benih setara $14.114 \mathrm{~kg}$.

Selain itu, pada Juli 2020, data KKP juga menunjukkan 100 perusahaan mendaftar permohonan ekspor lobster. Namun berdasarkan data pengecekan Tim Uji Tuntas Perizinan Usaha Perikanan Budi Daya Lobster, 
Kementerian Kelautan Perikanan menyatakan baru 30 perusahaan yang lolos kualifikasi (Ambari \& Jay, 2020).

Pada masa kepemimpinan Edhy Prabowo, Vietnam menjadi negara utama tujuan ekspor benih lobster. Vietnam menguasai 99,69 \% pangsa ekspor benih lobster RI dengan total US $\$ 33,89$ juta selama bulan Juni-Oktober 2020. Vietnam, Hongkong, dan Taiwan adalah termasuk salah satu konsumen terbesar dengan nilai ekspor benih lobster sebanyak US\$ 87.484 juta dan US\$ 17.370 (Thomas, 2020).

Berkaca dari pengalaman sebelum pemberlakuan Peraturan Menteri KP Nomor 1 Tahun 2015 tentang larangan penangkapan benih lobster di Indonesia, dalam kurun waktu 2009-2014 dapat dilihat bahwa Vietnam yang memicu lonjakan ekspor benih lobster di perairan Indonesia meskipun mengalami fluktuasi (Erlania et.al., 2017). Berikut salah satu data volume ekspor benih lobster daerah di Indonesia ke beberapa negara tujuan. 
Figur 3. Volume Ekspor Benih Lobster dari Indoensia ke Beberapa Negara Tujuan

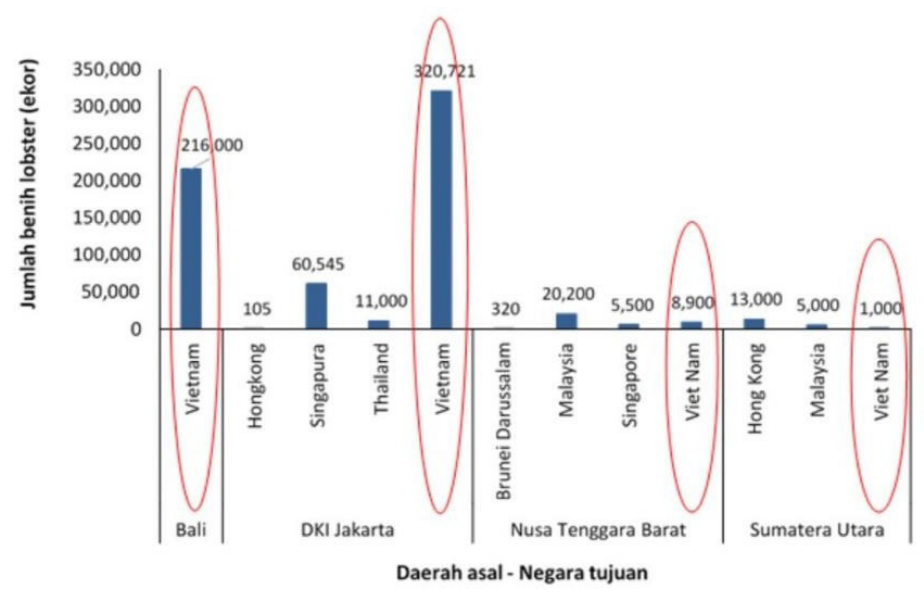

Sumber: BKIPM, 2015

Perkumpulan Budi daya dan Nelayan Lobster Indonesia (PBNLI) menyatakan adanya penahanan ekspor sebanyak 2,7 juta bibit losbter yang dilakukan oleh Bea Cukai pada Selasa (15/9) malam. Karena penahanan tersebut, banyak bibit lobster mati akibat terlalu lama ditahan oleh petugas. Pihak Bea Cukai menganggap bahwa ekspor benih lobster yang dilakukan oleh empat belas perusahaan tidak sesuai dengan dokumen yang tertera. Bea Cukai menggagalkan 1,2 juta bibit lobster dan telah menyelamatkan negara dari kerugian sebesar Rp1,2 miliar. Perkumpulan PBNLI menganggap kerugian negara akan lebih besar karena telah menggagalkan ekspor dan dalam hitungan mereka 
kerugiannya mencapai Rp36 miliar lebih atau US\$2,7 juta akibat devisa hilang (Rakhman, 2020).

Di balik keuntungan yang begitu besar, para peneliti dalam simposium internasional Kelautan dan Perikanan Ketiga pada September 2020 menulis bahwa kehidupan ekosistem laut terancam akibat ekspor benih lobster yang tidak bersifat ekonomi berkelanjutan. Selain itu, ekspor benih lobster juga dipandang hanya menempatkan nelayan sebagi buruh karena keuntungan yang didapat terlalu kecil. Susi Pujiastuti, Menteri KKP 2014-2019, dalam diskusi online bertema "Telaah Kebijakan Ekspor Benih Lobster" menyatakan bahwa ekspor benih lobster belum dilandasi pertimbangan teknologi budi daya lobster dan keberlanjutan sumber daya. Baginya, makna keberlanjutan sumber daya harus berbanding lurus dengan kesejahteraan lintas generasi sehingga negara harus menjamin untuk melindunginya (Doaly, 2020).

\section{KESIMPULAN}

Tindakan pemerintah yang membuka kembali keran ekspor benih lobster memicu munculnya suatu aksi tragedi sumber daya kepemilikan bersama. Kegiatan ekspor benih lobster tidak hanya melibatkan 
negara sebagai aktor yang terlibat langsung, tetapi juga masyarakat dalam mengambil bagian untuk memperoleh keuntungan pribadi maupun kolektif dengan memanfaatkan ekspor benih lobster.

Antusiasme publik menyambut diperbolehkannya lagi ekspor lobster, banyak diasumsikan untuk kesejahteraan nelayan dalam membangun perekonomian yang sempat terhambat. Mulai dari pelarangan ekspor oleh menteri Susi hingga pandemi yang melanda di tahun 2020. Selain itu, permintaan yang tinggi justru malah datang dari luar negeri karena tingkat konsumsi lobster bagi masyarakat Indonesia yang masih rendah. Hal tersebut memicu anggapan bahwa lebih baik melakukan ekspor ketimbang memasarkannya secara lokal. Harga yang ditawarkan dari ekspor benih lobster cenderung menggiurkan masyarakat sehingga kasuskasus penyeludupan ini menjadi warna dalam kegiatan ekspor.

Di balik keuntungan yang ditawarkan, eksportir banyak melakukan ekspor benih lobster tanpa melakukan budi daya seperti yang tercantum dalam Permen KP Nomor 12 sehingga hal ini kemudian menjadi persoalan utama dalam keberlangsungan ekosistem laut Indonesia. Kebijakan tersebut dapat memicu eksploitasi yang semakin marak tanpa memperhatikan ketentuan- 
ketentuan yang ada dalam naungan Permen KP Nomor 12 Tahun 2020.

Dorongan mendatangkan devisa menjadi salah satu alasan lahirnya Permen KP Nomor 12 Tahun 2020. Tetapi, kebijakan tersebut cenderung menciptakan inefisiensi pasar atau kegagalan pasar. Hal ini disebabkan karena ketidakmampuan untuk mengalokasikan sumbersumber ekonomi secara efisien dalam masyarakat akibat eksploitasiyang tidak memikirkankerbelanjutan. Orentasi keberlanjutan ekosistem laut akan menjadi problematik berkepanjangan bagi negara karena tindakan pendahulu yang tidak sesuai dengan regulasi yang ada. Akibatnya, kebijakan yang diharapkan membawa kesejahteraan bagi masyarakat khususnya bagi nelayan, justru akan menimbulkan efek yang tidak menguntungkan bagi negara, rakyat, dan sektor maritim. 


\section{REFERENSI}

Adhiatma, F., \& Putranti, IR. (2019). Efektivitas (RPOA) Rencana Aksi Regional Dalam Penanggulangan IUU Fishing Studi Kasus: Penyulundupan Ilegal Benih Lobster Indonesia ke Vietnam. Jurnal Hubungan Internasional, 5 (4), 780-788.

Ambari, Muhammad, \& Jay, F. (2020). Menyelamatkan Benih Lobster dari Eksploitasi Eksportir. Mongbay. co.id. Diakses dari https://www.mongabay. co.id/2020/ 07/07/menyelamatkan-benih-lobsterdari- eksploitasi-eksportir/.

BBC News Indonesia. (2020). Edhy Prabowo dan Kebijakan Ekspor Benih Lobster, Benarkah Membuat 'Everybody Happy'? Bbc.com. Diakses dari https://www.bbc. com/ indonesia/indonesia-55072847.

Bernhofen, D.M., \& Brown,J.C.(2018). OntheGenius Behind David Ricardo's 1817 Formulation of Comparative Advantage. Journal of Economic Perspectives, 32(4), 227- 240. https://doi.org/10.1257/jep.32.4.227.

BKIPM. (2019). 2015-2019, Pemerintah Berhasil Gagalkan 270 Kasus Penyelundupan Benih Lobster. Kkp. go.id. Diakses dari https://kkp.go.id/kkp/bkipm/ artikel/14352-2015-2019-pemerintah-berhasilgagalkan-270-kasus-penyelundupan-benih-lobster. 
Boediono, DR. (1982). Ekonomi Mikro. Edisi Kedua. Yogyakarta: BPFE.

Dina, K. B., Hasanah, H. (2020). Analisis Permen KP No. 12/2020 Terkait Kebijakan Ekspor Benih Lobster Berdasarkan Prinsip Pembangunan Berkelanjutan pada Era New Normal. Jurnal Hukum Lingkungan Indonesia. 7. 48-70.

Doaly, Themmy. (2020). "Ketika Susi Pudjiastuti Ikut Bahas Polemik Ekspor Benih Lobster.” Mongabay. Diakses dari https://www.mongabay.co.id/2020/07/28/ ketika-susi- pudjiastuti-ikut-bahas-polemik-eksporbenih-lobster/.

Erlania, E., Radiarta, I. N., \& Haryadi, J. (2017). Status Pengelolaan Sumber daya Benih Lobster untuk Mendukung Perikanan Budidaya: Studi Kasus Perairan Pulau Lombok. Jurnal Kebijakan Perikanan Indonesia, 8 (2), 85. https://doi.org/10.15578/ jkpi.8.2. 2016.85-96.

Fadli, A. (2019). Bola Liar Wacana Ekspor Benih Lobster dan Usaha Pembudidayaan. Alinea.id. Diakses dari https://www.alinea.id/bisnis/bola-liar-wacanaekspor-benihlobster-dan-problem-budi-dayab1XrI9qhq. 
Fitra,S.,\&Lidwina,A.(2020).Benih Dilarang,EksporLobster Benderang. Katadata.co.id. Diakses dari https:// katadata.co.id/o/analisisdata/5e9a57af96532/benihdilarang- ekspor-lobster-benderang.

Giddens, Anthony. (1990). The Consequences of Modernity. Polity Press. Cambridge.

Hidayatulla, T. (2020). Ekspor Benih Lobster Rugikan Negara dan Nelayan. Lokadata.id. Diakses dari https://lokadata.id/artikel/ekspor-benih-lobsterrugikan-negara-dan-nelayan.

Hikmah, Ulfah. (2020). "Korupsi Ekspor Benih Lobster Petaka Bagi Ekosistem Laut.” Greenpeace.org. Diakses dari https://www.greenpeace.org/indonesia/ cerita/ 44407/korupsi-ekspor-benih-lobster- petakabagi-ekosistem-laut/.

Hindmor, A., \& Taylor, B. (2018). Rational Choice. In V. Lowndes, D. Marsh, \& G. Stoker (Eds.), Theory and Methods in Political Science (4th ed., pp. 39-53). Palgrave. 
Idris, Muhammad. (2020). Apa Alasan Edhy Prabowo Cabut Larangan Ekspor Benih Lobster Era Susi? Kompas.com. Diakses dari https://money.kompas. com/read/ 2020/07/05/063501826/apa-alasanedhy-prabowo-cabut-larangan-ekspor-benih-lobsterera-susi?page=all\#: :text=Edhy menegaskan\%2C kebijakan pembukaan ekspor,pembudidayaan lobster di berbagai daerah.

Iskandar, J. (2006). The Challenge of Hardin'S Idea on the Tragedy of the Commons. Sosiohumaniora, 8 (1), 1-20.

Khairani Hila. (2015). Kepentingan Indonesia Melarang Ekspor Benih Lobster Ke Vietnam 2015. 151 (1), 10-17.

Lavinda. (2020). Devisa Adalah? Pengertian, Fungsi, dan Sumbernya. Jurnal Entrepreneur. Diakses dari https://www.jurnal.id/id/blog/devisa-pengertianfungsi-dan- sumbernya

Mankiw, N. G. (2012). Principles of Economic (Sixth Edit). South-Western Cengage Learning.

Moffitt, B. (2016). The Global Rise of Populism: Performance, Political Style, and Representation. Stanford University Press. 
Mukhlis, I. (2009). Eksternalitas, Pertumbuhan Ekonomi dan Pembangunan Berkelanjutan dalam Perspektif Teoritis. Jurnal Ekonomi Bisnis, 14 (3), 191-199.

Normal, New. (2020). Analisis Permen KP No. 12/202O Terkait Kebijakan Ekspor Benih Lobster Berdasarkan Prinsip Pembangunan Berkelanjutan pada New Normal (12).

Rahma, Athika. (2020). Penyebab Menteri KKP Edhy Prabowo Ditangkap KPK, Segini Harga Benih Lobster. Liputan6.com. Diakses dari https://www. liputan6.com/bisnis/ read/4418349/penyebabmenteri-kkp-edhy-prabowo-ditangkap-kpk-seginiharga-benih-lobster\#: :text=Liputan6.com\%2C Jakarta Menteri KKP,ekspor benih lobster atau benur.\&text=Berdasarkan data PPATK\%2C.

Rakhman, Ridwansyah. (2020). PBNLI: Ekspor Lobster Digagalkan Bea Cukai, Negara Berpotensi Kehilangan Devisa Rp36 Miliar. Akurat.co. Diakses dari https:// akurat.co/ekonomi/id-1214987-read-pbnli-eksporlobster-digagalkan-bea- cukai-negara-berpotensikehilangan-devisa-rp36-miliar?page=1.

Redaksi. (2020). Bahaya Ekspor Benih Lobster. Forest Digest. Retrieved from https://www.forestdigest. com/detail/897/ekspor-benih-lobster-dihentikan. 
Rezkisari, I. (2020). Ekspor Benih Lobster yang Bermasalah dari Hulu ke Hilir. Republika.co.id. Diakses dari https://republika.co.id/berita/qklqfx328/eksporbenih-lobster-yang-bermasalah-dari-hulu-ke-hilir.

Rosana, F. C. (2020). Terlalu Murah, Harga Benih Lobster di Nelayan Hanya Rp

4.00o. Tempo.co. Diakses dari https://bisnis.tempo.co/ read/1355786/terlalu-murah-harga-benih-lobster-dinelayan-hanya-rp-4-ooo.

Rosana, Fransisca Christy, Eko Wahyudi, and Ferry Firmansyah. (2020). "Nelayan Menduga Eksportir Akali Aturan Ekspor Benih.” Koran.tempo.co. Diakses dari https://koran.tempo.co/read/ekonomi-danbisnis/455319/nelayan-menduga- eksportir-akaliaturan-ekspor-benur.

Tambunan, Tulus. (2001). Transformasi Ekonomi di Indonesia: Teori dan Penemuan Empiris. Jakarta: Salemba Empat.

Thomas, Vincent Fabian. (2020). Sebelum Edhy Ditangkap KPK, Ekspor Benih Lobster RI 33,99 Juta USD. Tirto.id. Diakses dari https://tirto.id/sebelum-edhyditangkap-kpk- ekspor-benih-lobster-ri-3399-jutausd-f7oS. 
Thomas, V. T. (2020) . Ekspor Benih Lobster RI ke Vietnam September 2020 Naik 135 Persen. Tirto.id. Diakses dari https://tirto.id/ekspor-benih-lobster-ri-kevietnam-september-2020-naik-135-persen-f555.

Victoria, Agatha Olivia. (2020). Pemerintah Bayar Cicilan Utang, Cadangan Devisa November Turun Tipis. Katadata.co.id. Diakses dari https://katadata.co.id/ agustiyanti/finansial/5fcdcc9f9f $169 /$ pemerintahbayar-cicilan- utang-cadangan-devisa-novemberturun-tipis.

Victoria, Widya. (2020). Ekspor Benih Lobster Rugikan Perekonomian Nasional. Ayojakarta.com. Diakses dari https://www.ayojakarta.com/read/2019/12/19/ 9838/ekspor-benih-lobster-rugikan-perekonomiannasional.

Wahyudi, E. (2020). KNTI Sebut Harga Jual Benih Lobster Ekspor 10 Kali dari Nelayan. Bisnis.tempo.co. Diakses dari https://bisnis.tempo.co/read/1364373/kntisebut- harga-jual-benih-lobster-ekspor-10-kali-darinelayan.

Wicaksono, A. (2020). Luhut Akui Ada Praktik Monopoli Pengangkutan Ekspor Benur. Cnnindonesia.com. Diakses dari https://www.cnnindonesia.com/ ekonomi/ 20201127191425-92-575505/luhut-akuiada-praktik-monopoli-pengangkutan-ekspor-benur. 
Sherlly Rossa, Silvestra Gratiana Tyas Vita Wimasari, Sulis Rahmawati, dan

Teddy Aprilianto Thomas

Witomo, C. M., \& Nurlaili, N. (2015). Strategy of Sustanibility Seed Lobster Management in Lombok. Jurnal Kebijakan Sosial Ekonomi Kelautan dan Perikanan, 5, 11-18. 